\title{
PRODUCTIVITY AND QUALITY OF TOMATO SUBMITTED TO IRRIGATION LEVELS USING MULCHING IN ECONOMIC BEDS
}

\section{PARÂMETROS PRODUTIVOS DO TOMATE SUBMETIDO A LÂMINAS DE IRRIGAÇÃO UTILIZANDO MULCHING EM CANTEIROS ECONÔMICOS}

\author{
Rivonaldo Batista da Cruz ${ }^{1} \oplus$, Edimir Xavier Leal Ferraz ${ }^{2} \oplus$, Isaac Lima Simões de \\ Vasconcelos $^{2} \oplus$, Carlos André de Souza Sá ${ }^{3 \oplus}$, Renato Veríssimo da Silva Filho ${ }^{4} \oplus$, Raquele \\ Mendes de Lira ${ }^{5}$, Antônio Henrique Cardoso do Nascimento ${ }^{6}$
}

\footnotetext{
${ }^{1}$ Graduado em Agronomia, UFRPE/UAST, Departamento de Agronomia, Serra Talhada, PE, Brasil.

${ }^{2}$ Graduando em Agronomia, UFRPE/UAST, Departamento de Agronomia, Serra Talhada, PE, Brasil.

${ }^{3}$ Mestrando em Engenharia agrícola, UNIVASF, PGEA, Petrolina, PE, Brasil.

${ }^{4}$ Mestrando em Ciências dos solos, UFRPE/SEDE, PGS, Recife, PE, Brasil.

${ }^{5}$ Professora Doutora em Engenharia agrícola, UFRPE/UAST, Departamento de Agronomia, Serra Talhada, PE, Brasil.

${ }^{6}$ Professor Doutor em Engenharia agrícola, UFRPE/UAST, Departamento de Agronomia, Serra Talhada, PE, Brasil.
}

\begin{abstract}
The objective of this study was to evaluate irrigation levels in tomato crops, using economical beds with mulch. A randomized block design within a split-plot had run in a 2 x 5 factorial treatment scheme structure, with four replications. The plots were the five irrigation levels $(50,75,100,125$, and 150\%) of crop Evapotranspiration (ETc), and subplots were two tomato varieties RASTEIRO RIO GRANDE (RR) (Lycopersicon lycopersicum) and CALINE IPA- 7 (IPA) (Lycopersicon esculentum Mill.). In the end, 40 experimental units consisting of five plants each were evaluated. The variables assessed were tomato productivity (PROD), fruit mass (FM), volume (VOL), fruit diameter (DIA), titratable acidity (TA), hydrogen potential $(\mathrm{pH})$, soluble solids ( ${ }^{\circ}$ Brix), and soluble solids/titratable acidity ratio (SS/AT). The results showed that the irrigation level of $117.85 \%$ of ETc provide greater productivity for a cultivar RASTEIRO RIO GRANDE, while for CALINE IPA-7, it was $150 \%$ of ETc. The variety CALINE IPA-7 had higher acidity content and lower soluble solids/titratable acidity ratio. The addition of irrigation levels influenced a decrease in acidity content by applying levels of up to $125 \%$ of ETc.
\end{abstract}

Keywords: Evapotranspiration, Lycopersicon esculentum L., Northeastern semiarid.

RESUMO: Objetivou-se com esse trabalho avaliar lâminas de irrigação na cultura do tomateiro, utilizando canteiros econômicos com mulching. A pesquisa foi conduzida na Universidade Federal Rural de Pernambuco em Serra Talhada - Pernambuco. Utilizou-se delineamento em blocos casualizados sob parcelas subdivididas, em esquema fatorial ( 5 x 2), no qual, avaliou-se como parcelas 5 lâminas de irrigação $(50,75,100,125 \mathrm{e}$ $150 \%$ da Evapotranspiração da Cultura - ETc), e subparcelas duas variedades de tomateiro RASTEIRO RIO GRANDE (RR) (Lycopersicon lycopersicum) e CALINE IPA- 7 (IPA) (Lycopersicon esculentum Mill.), com quatro repetições, totalizando 40 unidades experimentais. Foram avaliadas a produtividade do tomateiro (PROD), a massa dos frutos (MF), o volume (VOL), o diâmetro dos frutos (DIA), acidez titulável (AT), potencial hidrogeniônico $(\mathrm{pH})$, sólidos solúveis ( $\left.{ }^{\circ} \mathrm{Brix}\right)$, e a relação dos sólidos solúveis com acidez titulável (SS/AT). Constatou-se que a lâmina de irrigação de 117,85\% da ETc proporciona uma produtividade de 4,68 kg. planta-1 para a cultivar RASTEIRO RIO GRANDE, enquanto para a CALINE IPA-7 foi a de $150 \%$ da ETc. A variedade CALINE IPA-7 apresentou maior acidez e menor relação sólidos solúveis e acidez titulável. O acréscimo da lâmina de irrigação proporciona diminuição nos níveis de acidez ao se aplicar uma lâmina de até $125 \%$ da ETc.

Palavras-chave: Evapotranspiração, Lycopersicon esculentum L., Semiárido nordestino. 


\section{INTRODUCTION}

Irregularities in rainfall behavior and distribution across the semi-arid region of the Northeast of Brazil lead to severe drought periods, compromising agricultural food production when carried out in a rainfed system, especially for crops with high water demand (CASSIMIRO et al., 2019). According to Bispo et al. (2017) and Valeriano et al. (2016), irrigation is an important technique for water supply and optimizing the productivity of various crops, nevertheless, inadequate management of the irrigation system and culture can make the production process impracticable. Thus, the use of technologies and management to save water is needed.

According to Cassimiro (2019), the economic beds constitute a social technology that aims to mitigate the inefficient use of water for vegetables production. These types of beds prevent outflow by conditioning a waterproofing the planted land, in addition to subsurface irrigation that reduces evaporation losses. Baumgartner et al. (2007) affirm that the use of economic beds contributes to an increase in the quantity and quality of harvested products; another advantage is the low cost of these systems. Furthermore, if the economic beds are associated with the use of mulching (plastic covering), whose purpose is to maintain moisture when on the ground, it will be possible to promote water savings without losses in plant yield and food quality (YURI et al., 2012). Among the most cultivated crops in economic beds, tomato plant has great water demand. Thus, the correct use of water can promote better productivity. In this sense, studies are testing different irrigation levels in tomato plants (SANTIAGO et al., 2018; SILVA et al., 2020 $\&$ SOARES et al., 2013); however, studies on economic beds using mulching were not found in the available scientific literature.

It is believed that with the reduction of evapotranspiration, lower irrigation levels can provide similar productivity and fruit quality.

Hence, the objective of this study was to evaluate different irrigation levels in the tomato crop, using the economic beds with mulching in order to find the irrigation levels that provide the highest productivity and fruit quality under these conditions.

\section{MATERIAL AND METHODS}

The experiment was conducted from August 2018 to March 2019, at the Federal Rural University of Pernambuco, at the Serra Talhada Academic Unit (UFRPE/UAST), in the municipality of Serra Talhada, located at the geographic coordinates of $7^{\circ} 57^{\prime} 10^{\prime \prime} \mathrm{S}$ and $38^{\circ} 17^{\prime} 43^{\prime \prime} \mathrm{W}$, at an altitude of 429 meters (SIRGAS 2000), in Mesoregion of Sertão Pernambucano, Brazil. According to the classification of Köppen, the climate type in the region is BSw'h'. The average annual rainfall is $639 \mathrm{~mm}$, with an average annual temperature of around $25.2^{\circ} \mathrm{C}$ (LAMEPE/ITEP, 2017).

A randomized block design within a split-plot had run in a $2 \times 5$ factorial treatment scheme structure, with four replications. The plots were the five irrigation levels $(50,75$, $100,125$, and $150 \%)$ of crop Evapotranspiration (ETc), and subplots were two tomato varieties RASTEIRO RIO GRANDE' (Lycopersicon lycopersicum) and 'CALINE IPA- 7' (Lycopersicon esculentum Mill.). In the end, 40 experimental units consisting of five plants each were evaluated.

Twenty beds of $3 \mathrm{~m}^{2}$ ( $\left.3 \mathrm{~m} \times 1 \mathrm{~m}\right), 0.20 \mathrm{~m}$ deep were built, leveled in transverse and longitudinal directions, to keep each layer level, favoring a uniform distribution of water (WIN, 2007). Subsequently, they were filled with substrate prepared in the proportion of $2: 3: 4$, of sand, soil, and cattle manure, respectively, mixed until homogenized. The coverage with mulching was carried out after the beds' installation.

The seedlings were produced in plastic trays, cultivated in sand and humus substrate (2:1), keeping it always moist, in a protected environment, and covered by shading at $50 \%$ for 15 days after germination and then $25 \%$ for another 12 days. The seedlings of the two varieties were distributed equidistantly in the 
beds every $0.3 \mathrm{~m}$, totaling ten plants per bed, with five plants for each cultivar.

Irrigation levels were calculated based on the crop evapotranspiration (ETc) according to the equation proposed by Allen et al. (1998). The reference evapotranspiration was determined by the Class A Tank methodology.

At harvest time, the tomato productivity was evaluated, according to Alvarenga (2004), obtaining the commercial fruits in each treatment. The fruits mass (FM) was determined using a semi-analytical balance. The volume (VOL) was determined with the aid of a cup of water, in which the fruits were immersed.

For the VOL calculation, the initial level of the water was subtracted from the final level of the immersion. Fruit diameter (DIA) was obtained using a caliper. From the fruit mass, it was possible to determine the productivity of fruit per plant (PROD). Additionally, the quality parameters of tomato fruits were obtained, such as titratable acidity
(TA), Hydrogen Potential (HP), soluble solids ( ${ }^{\circ}$ Brix), and soluble solids/titratable acidity ratio (SS/TA), according to Adolfo Luts Institute's methodology for food analysis (2008).

The results were submitted to analysis of variance to evaluate the effects of different irrigation levels and cultivars. When significant, the effects of irrigation regimes were assessed by regression analysis using the SIGMA PLOT 12.0 software. For the effect of the cultivars, the Tukey test was adopted, at $5 \%$ probability, using the statistical program Sisvar 5.6 (FERREIRA, 2019).

\section{RESULTS AND DISCUSSION}

The results from the analysis of variance demonstrated that the variables FM, VOL, and PROD had a significant effect $(\mathrm{P}<0.01)$. There was an interaction between irrigation levels and cultivars only for variable productivity $(\mathrm{P}<0.01) \quad$ (Table

Table 1. Analysis of variance table of the variables: Fruit mass (FM), fruit diameter (DIA), fruit volume (VOL), and productivity (PROD) of tomato under different irrigation levels.

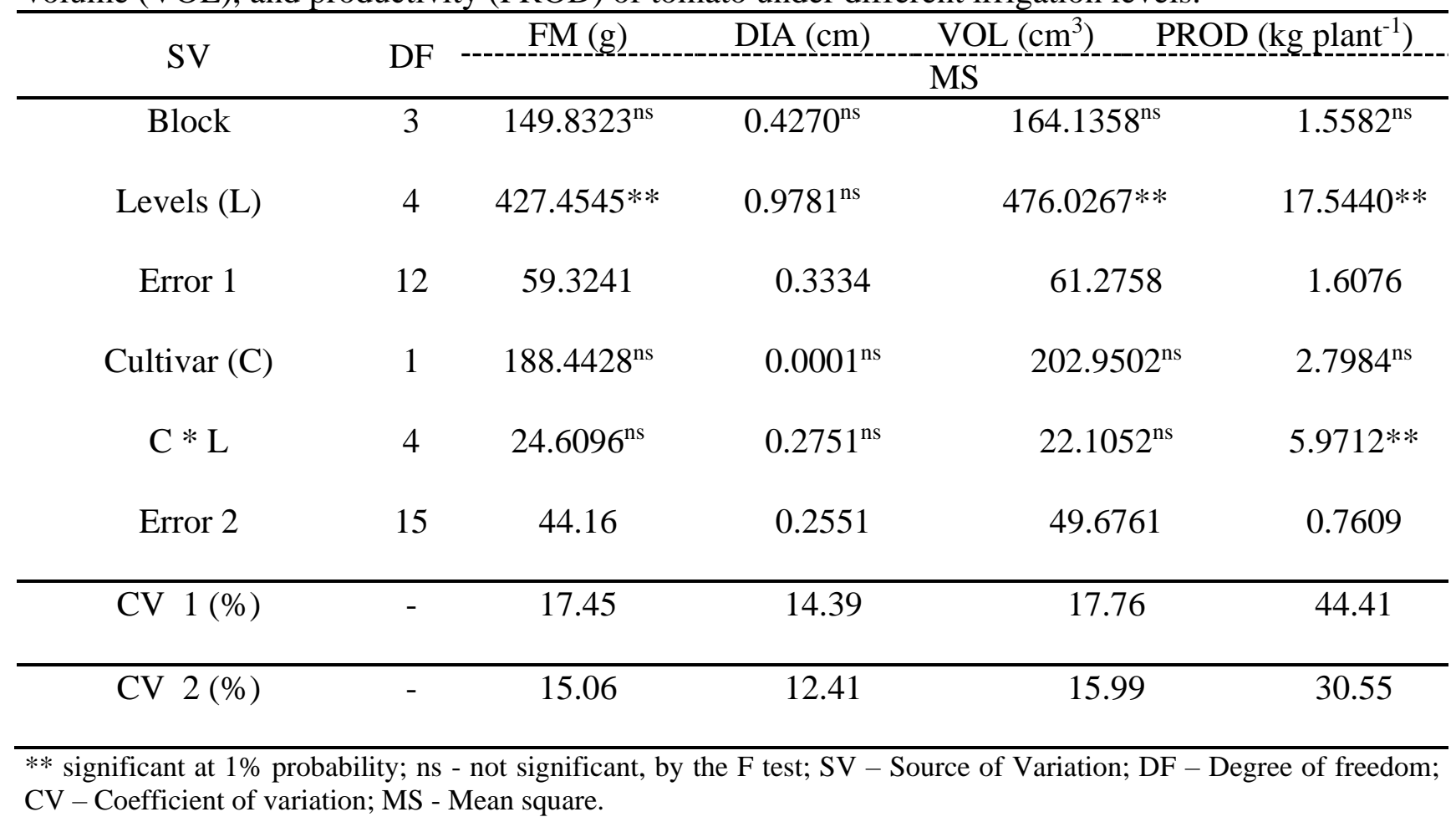


According to Figure 1, there was a linear increase for both volume (A) and fruit mass (B) of tomato on irrigation levels used in the experiment.

Although the irrigation levels are greater than $100 \%$ of the recommended ETc, the increase in water availability can provide a higher volume to the fruits due to the source and drain relation in the water movement in the plant, also providing greater weight. Furthermore, the level corresponding to $150 \%$ of ETc provided increases in the variables VOL (A) and FM (B), of 20.5 and $18.5 \%$, in relation to the level of $100 \%$.
A

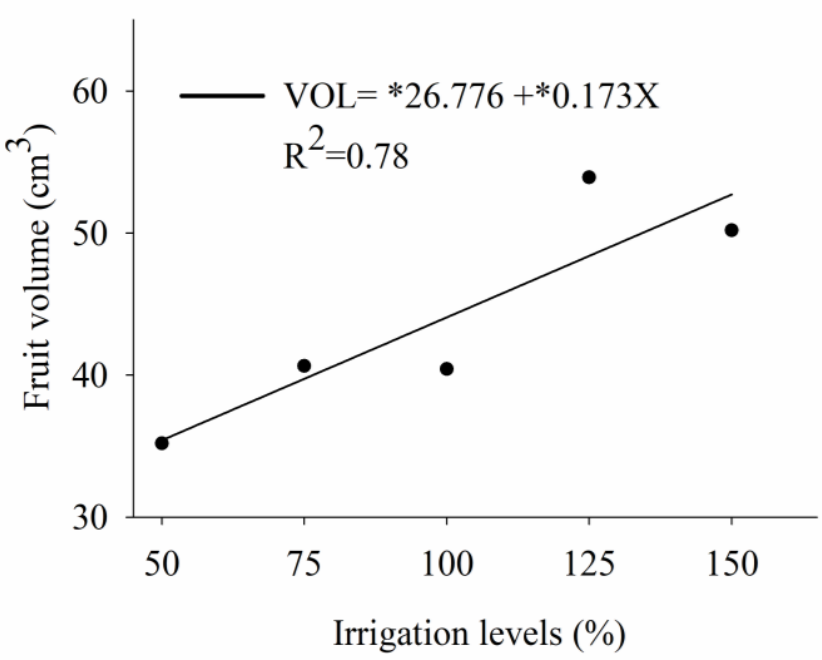

B

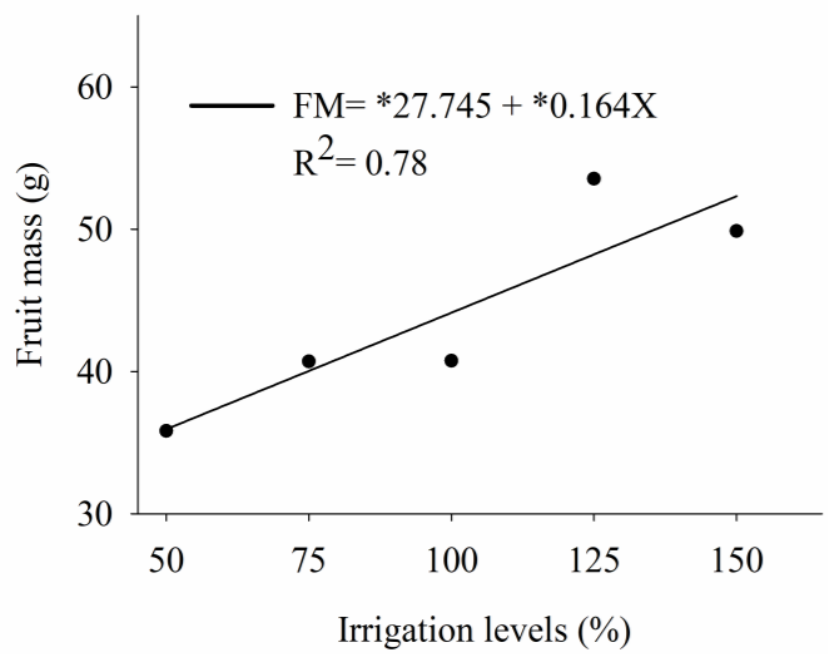

Figure 1. Volume (A) and mass (B) of Tomato fruit on different irrigation levels.

* Significant coefficient at $5 \%$ probability.

Ansary et al. (2017) affirm that the increase in the weight of fruits per plant could be related to an improved microclimate, below and above the soil surface, using plastic coverings. In this investigation, economical beds and plastic cover were used, which probably have led to a lower water loss from the soil to the atmosphere, granting the proper crop supply and favoring higher yields. A similar effect was observed by Bin et al. (2021) when testing different water replacements with and without the use of plastic cover in tomato plants. These authors noted that the increased water availability expanded the tomatoes' productivity, and the use of plastic covering provided greater results. Figure 2 shows the tomato productivity under different irrigation levels. It was observed a linear increase of the variety CALINE IPA-7 (IPA) cultivated with a maximum yield of $4.44 \mathrm{~kg}$ plant-1, using the
150\% ETc level. Silva et al. (2014), who worked with the same cultivar, found a lower productivity than observed in this study. The referred authors obtained a value of $1.94 \mathrm{~kg}$ plant-1 for an irrigation level of $150 \%$ of the ETc, with a productive increment of $110 \%$ in relation to the depth of $50 \%$. Whereas, in this study, a productivity had an increment of $590 \%$ compared to the same level.

For the variety RASTEIRO RIO GRANDE (RR) (Figure 2), a quadratic behavior was observed, maximum productivity (4.68 kg plant-1) with estimated irrigation levels, corresponding to $117.85 \%$ of the ETc was obtained. According to Silva et al. (2020), who studied the development of industrial tomato under different irrigation levels using the BRS Sena hybrid, the excess and deficit of water affect the development of the tomato, including flowering and fruiting of the crop, directly affecting its productivity. 
Productivity and quality of tomato submitted to irrigation levels using mulching in economic beds

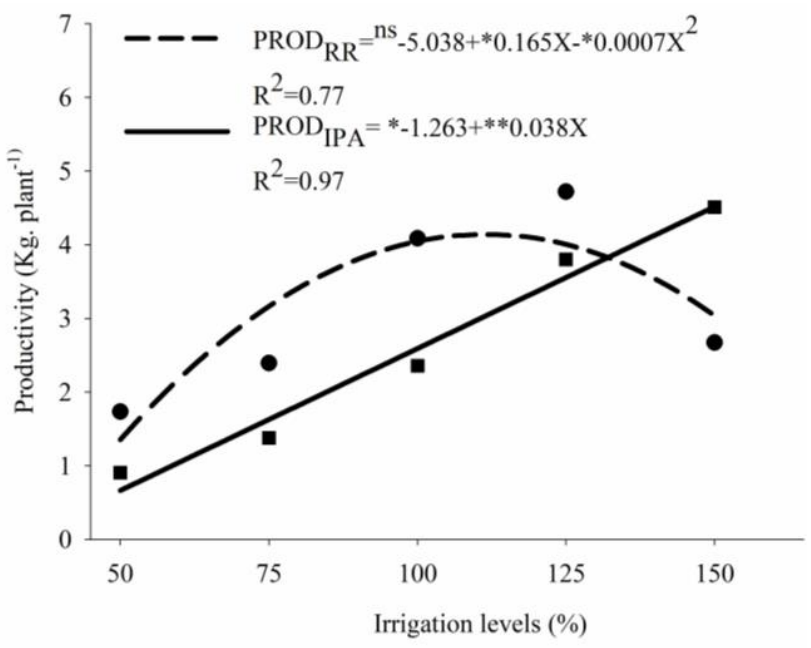

Figure 2. Productivity of tomato cultivars under different irrigation levels.

* Significant coefficient at $5 \%$ probability; and ** $1 \%$ probability.

Table 2 shows the analysis of variance of qualitative parameters of tomato. The results indicated a significant effect just for titratable acidity (TA) on level (L). About the factor cultivar $(\mathrm{C})$, only the variables titratable acidity (TA) and soluble solids/titratable acidity ratio (SS/TA) differed significantly $(\mathrm{P}<0.01)$.

Table 2. Analysis of variance table of the variables: titratable acidity (TA), soluble solids (SS), $\mathrm{pH}$ and soluble solids/titratable acidity ratio (SS/TA) of tomato plants submitted to different irrigation levels.

\begin{tabular}{|c|c|c|c|c|c|}
\hline \multirow{2}{*}{ SV } & \multirow{2}{*}{ DF } & $\mathrm{pH}$ & SS & $\mathrm{TA}$ & SS/AT \\
\hline & & \multicolumn{4}{|c|}{$\mathrm{MS}$} \\
\hline Block & 3 & $0.03347^{\mathrm{ns}}$ & $0.3752^{\mathrm{ns}}$ & $0.0402^{\mathrm{ns}}$ & $5.2906^{\mathrm{ns}}$ \\
\hline Level (L) & 4 & $0.0244^{\mathrm{ns}}$ & $1.3856^{\mathrm{ns}}$ & $0.0857 *$ & $4.0513^{\mathrm{ns}}$ \\
\hline Error 1 & 12 & 0.0158 & 0.4483 & 0.0229 & 1.8015 \\
\hline Cultivar (C) & 1 & $0.0164^{\mathrm{ns}}$ & $0.4622^{\mathrm{ns}}$ & $0.4553 * *$ & $69.1926 * *$ \\
\hline $\mathrm{C} * \mathrm{~L}$ & 4 & $0.0099^{\mathrm{ns}}$ & $0.0460^{\mathrm{ns}}$ & $0.0203^{\mathrm{ns}}$ & $2.5300^{\mathrm{ns}}$ \\
\hline Error 2 & 15 & 0.0171 & 0.3592 & 0.0224 & 2.6156 \\
\hline CV $1(\%)$ & - & 2.98 & 7.44 & 17.30 & 12.55 \\
\hline $\mathrm{V} 2(\%)$ & - & 3.10 & 6.66 & 17.09 & 15.12 \\
\hline
\end{tabular}

* Significant coefficient at 5\% probability; ** significant at 1\% probability; ns - not significant, by the F test; SV Source of Variation; DF - Degree of freedom; CV - Coefficient of variation. MS - Mean square 
When analyzing the factor Cultivar (C), it was noticed that the variety CALINE IPA-7 presented a higher acidity content (Figure 3A), which probably led to a lower soluble solids/titratable acidity ratio (Figure 3B). According to Vieira et al. (2014), tomato fruits could be considered mild flavor when they have a SS/TA ratio greater than ten due to the excellent combination of sugar and acid, as observed in the fruits of the cv. RR. On the other hand, values lower than ten could lead to fruit with an unpleasant or astringent taste, as the fruits of the $\mathrm{cv}$. IPA.
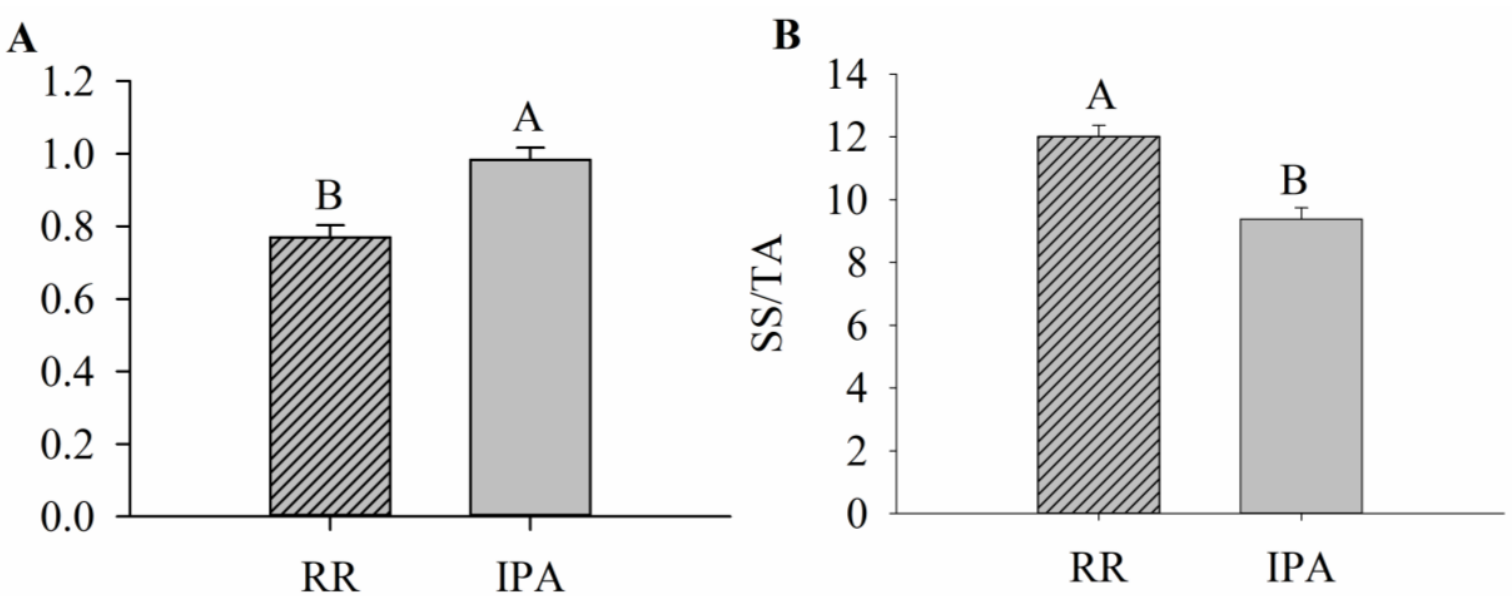

Varieties

Figure 3. Titratable acidity (TA) and soluble solids/titratable acidity ratio (SS/TA) for tomato under different irrigation levels. (Different letters indicate statistical difference by Tukey test, $\mathrm{p}<0.05$ ).

Regarding the acidity of tomato fruits, it was noticed (Figure 4) that the increase in the irrigation levels provided a quadratic decrease in the titratable acidity levels, obtaining the lowest result when applying $125 \%$ of ETc. Likewise, Santiago et al. (2018), when testing irrigation levels in tomato plants in a protected environment and open field, observed a reduction in titratable acidity with increasing levels, indicating that the higher the level of water replacement, the lower the content of soluble acids in the tomato fruits.
Furthermore, Marquelli \& Silva (2008) noted that higher soil water tensions provided linear growth in titratable acidity.

Portes et al. (2006) point out that under conditions of low water availability in the soil, various metabolic processes of plants are affected, leading to reductions of stomatal conductance, photosynthesis, and transpiration, and stomatal closure. As consequence, it can reduce the fruit quality, producing, for example, fruits with high acidity. 


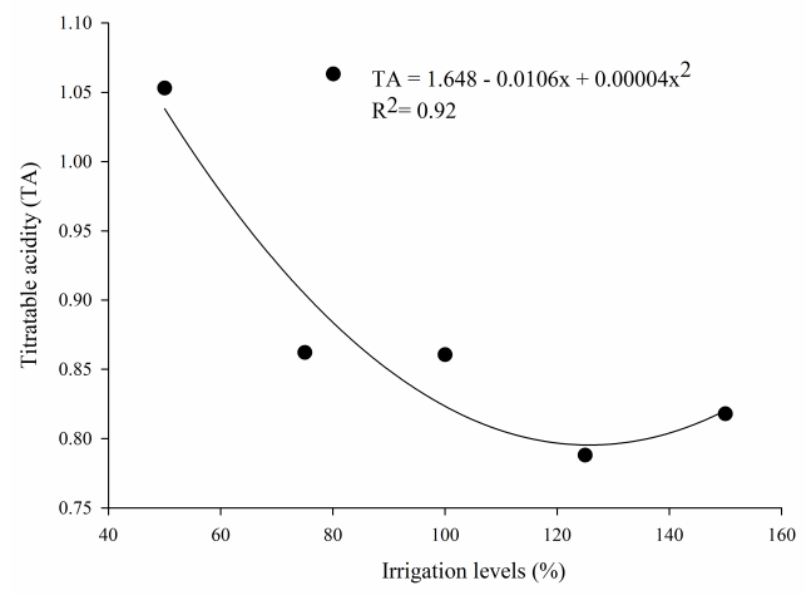

Figure 4. Titratable acidity depending on the different irrigation levels.

* significant at $5 \%$ probability; ${ }^{\text {ns }}$ not significant.

\section{CONCLUSION}

The irrigation levels of $117.85 \%$ of ETc provide the yield of $4.68 \mathrm{~kg}$. Plant- 1 for the cultivar 'RASTEIRO RIO GRANDE' while for the 'CALINE IPA-7', it was $150 \%$ of Etc. The variety CALINE IPA-7 exhibited higher acidity 18ontente and lower soluble solids/titratable acidity ratio. The addition of irrigation levels influenced a decrease in acidity 18 ontente by applying levels of up to $125 \%$ of Etc.

\section{REFERENCES}

ALLEN, R. G.; PEREIRA, L. S.; RAES, D.; SMITH, M. Crop evapotranspiration: Guidelines for computing crop water requirements. Rome: FAO, (FAO Irrigationand Drainage Paper, 56), p. 300, 1998.

ALVARENGA, M.A.R. Tomate: produção em campo, em casa-de-vegetação e em hidroponia. Lavras: UFLA, p. 400, 2004.

ANSARY, S. H.; MANNA, A.; BARUI, K.; MUDI, N.; GAYEN; CHOWDHURY, A.K. Evaluation of different mulch materials on growth and yield of summer tomato (Solanum lycopersicum L.). International
Journal of Tropical Agriculture, v. 35, n. 1, p. 47-55, 2017.

BAUMGARTNER, D; SAMPAIO, S. C.; SILVA, T. R. da; TEO, C. R. P. A.; BOAS, M. A. V. Reuso de águas residuárias da piscicultura e da suinocultura na irrigação da cultura da alface. Engenharia Agrícola, p. 152-163, 2007.

BIN， G.; YAN, M.; ZHONGDONG, W.; YANQUN, Z.; YU; SHIHONG, Y.; JIANDONG, W.; QIAOLING, L. Efeito do controle de mulching e umidade sobre o rendimento e qualidade dos tomates de irrigação por gotejamento nas instalações de Ningxia. Diário de Irrigação e Drenagem, n. 3, p. 48-55, 2021.

BISPO, R. de C.; FLORES, D. S.; NETA, H. B. dos S.; VENTURA, K. M.; QUEIROZ, S. $O$. P. Manejo de irrigação para cultivo de pimentão em ambiente protegido. In: IV INOAGRI INTERNATIONAL MEETING. Acesso em: dezembro. 2017. p. 2018.

CASSIMIRO, C. A. L. Canteiros econômicos: Tecnologia social e agroecológica no cultivo de olerícolas. 2019. Monografia (Trabalho de Conclusão do Curso de Tecnologia em Agroecologia) Instituto 
Federal de Educação, Ciência e Tecnologia da Paraíba, Sousa, f.58, 2019.

CASSIMIRO, C. A. L.; OLIVEIRA FILHO, F. S.; SILVA, E. D.; FEITOSA, S. S.; SIQUEIRA, E. C.; SILVA, M. G. Lâminas de água múltiplas via sistema de irrigação subsuperficial no cultivo de alface do grupo crespa. Revista Brasileira de Gestão Ambiental. v. 13, n. 1, p. 08-12, 2019.

COLLA, G; CASA, R.; LO CASCIO, B.; SACCARDO, F.; TEMPERINI, O.; LEONI, C. Response of processing tometo to water regime and fertilization in central italy. Acta horticulturae. The Hague, v.487. p. 531-555, 1999.

DA SILVA, C. J.; FRIZZONE, J.A.; DA SILVA, C. A.; PONTES, N. De C.; DA SILVA, L.F.M.; BASILIO, E. E. Desenvolvimento do tomateiro industrial em resposta a diferentes níveis de irrigação. IRRIGA, v. 25, n. 3, p. 432-448, 2020.

FERREIRA, D. F. Sisvar: a computer analysis system to fixed effects split plot type designs. Revista Brasileira de Biometria, v. 37, n. 4, p. 529-535, 2019.

GUALBERTO, R.; OLIVEIRA, P. S. R.; GUIMARÃES, A. M. Desempenho de cultivares de tomateiro para mesa em ambiente protegido. Horticultura Brasileira, v. 25, n. 2 , p. 244-246, 2007.

INSTITUTO ADOLFO LUTZ. Métodos físico-químicos para análise de alimentos. São Paulo: Instituto Adolfo Lutz, p. 1020, 2008.

LAMEPE/ITEP. Informações climáticas do Estado de Pernambuco, 2017.

MACÊDO, L. S.; ALVARENGA, M. A. R. Efeitos de lâminas de água e fertirrigação potássica sobre o crescimento, produção e qualidade do tomate em ambiente protegido. Ciência e Agrotecnologia, v. 29, n. 2, p. 296304, 2005.
MANTOVANI, E.C.; BERNARDO, S.; PALARETTI, L.F. Irrigação: princípios e métodos. 3. ed., atual. e ampl. Viçosa, MG: UFV. P. 355, 2009.

MARQUELLI, W. A; SILVA, W. L.C. Tensões - limite de água no solo para o cultivo do tomateiro para processamento irrigado por gotejamento Brasília: Embrapa Hortaliças, (boletim de pesquisa e desenvolvimento 37), p.17, 2008.

MORAIS, N. B.; BEZERRA, F. M. L.; MEDEIROS, J. F.; CHAVES, S. W. P. Resposta de plantas de melancia cultivadas sob diferentes níveis de água e de nitrogênio. Revista Ciência Agronômica, v.39, p.369377, 2008.

PORTES, M. T.; ALVES, T. H. e SOUZA, G. $M$. Water deficit affects photosynthetic induction in Bauhinia forficata Link (Fabaceae) and Esenbeckia leiocarpa Engl. (Rutaceae) growing in understorey and gap conditions Brazilian Journal of Plant Physiology, Londrina, v. 18, n. 4, p. 491-512, 2006.

SANTIAGO, E. J. P.; OLIVEIRA, G. M.; LEITAO, M. M. V. B. R.; ROCHA, R. C.; PEREIRA, A. V. A. Qualidade do tomate cereja cultivado sob lâminas de irrigação em ambiente protegido e campo aberto. Agrometeoros, v. 26, p. 213-221, 2018.

SILVA, J. A.; DUTRA, A. F.; CAVALCANTI, N. M. da S.; MELO, A. S. de; SILVA, F. G. da; SILVA, J. M. Aspectos agronômicos do tomateiro "Caline Ipa 6" cultivado sob regimes hídricos em área do semiárido. Revista Agro@mbiente On-line, v. 8, n. 3 , p. 336-344, 2014.

SOARES, L. A. A.; BRITO, M. E. B.; SILVA, E. C. B.; SÁ, F. V. S.; ARAÚJO, T. T. DE. Componentes de produção do tomateiro sob lâminas de irrigação nas fases fenológicas. Revista Verde de Agroecologia e Desenvolvimento Sustentável, v. 8, p. 8490, 2013. 
SOARES, L. A. A.; LIMA, G. S.; BRITO, M. E. B.; SÁ, F. V.; ARAÚJO, T. T. Crescimento do tomateiro e qualidade física dos frutos sob estresse hídrico em ambiente protegido. Revista Verde de Agroecologia e Desenvolvimento Sustentável, v. 6, n. 3, p. 203-212, 2011.

SCHWARZ, K., DE RESENDE, J. T. V., PRECZENHAK, A. P., DE PAULA, J. T., FARIA, M. V., \& DIAS, D. M. Desempenho agronômico e qualidade físico-química de híbridos de tomateiro em cultivo rasteiro. Horticultura Brasileira, v. 31, n. 3, p. 410-418, 2013.

VALERIANO, T. T. B.; SANTANA, M. J. D.; OLIVEIRA, A. F.; MACHADO, L. J. M. Alface americana cultivada em ambiente protegido submetida a doses de potássio e lâminas de irrigação. Irriga, Botucato, Sp, v. 3, n. 21, p.620-630, 22 ago. 2016.

VIEIRA, D. A. P.; CARDOSO, K. C. R.; DOURADO, K. K. F.; CALIARI, M.; JÚNIOR, M. S. S. Qualidade física e química de mini-tomates Sweet Grape produzidos em cultivo orgânico e convencional. Revista Verde, v 9, n. 3, p. $100-108,2014$.

YURI, J. E.; RESENDE, G. M.; COSTA, N. D.; MOTA, J. H. Strawberry cultivation with mulch of different colors and installation times on the beds. Horticultura Brasileira. Vitória da Conquista, v. 30 p. 424-427, 2012.

WIN, U. D. Técnicas de captação e uso da água no Semiárido brasileiro: canteiros econômicos em água. SIMPÓSIO BRASILEIRO DE CAPTAÇÃO E MANEJO DE ÁGUA DE CHUVA, v. 6, 2007. 